\title{
Penataan Wilayah pada Masa Kerajaan Sunda
}

\section{Agus Aris Munandar}

Keywords: history, archaeology, Hindu-Buddhist, Kingdom of Sunda, West Java

\section{How to Cite:}

Munandar, A.A. Penataan Wilayah pada Masa Kerajaan Sunda. Berkala Arkeologi, 14(2), 95-105. https:/ / doi.org/10.30883/jba.v14i2.706

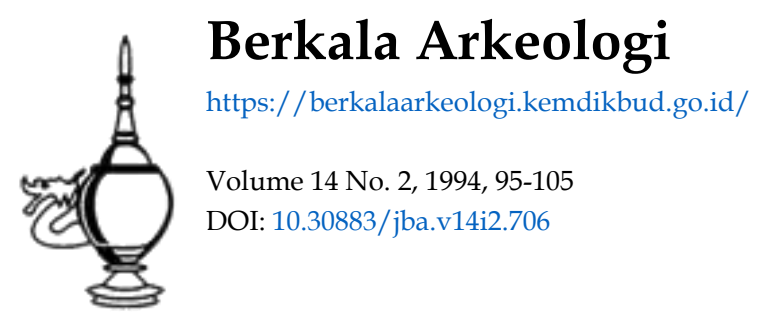

\section{(c) (1) (5)}

This work is licensed under a Creative Commons Attribution-NonCommercial-ShareAlike 4.0 International License. 


\title{
PENATAAN WILAYAH PADA MASA KERAJAAN SUNDA
}

\author{
Agus Aris Munandar
}

(Jurusan Arkeologı FSUI)

1.

Kerajaan Sunda adalah salah satu kerajaan dalam masa Hindu-Buddha yang terletak di Jawa Barat. Tidak seperti sejarah kerajaan-keraJaan laınnya yang pernah tumbuh dan berkembang di Pulau Jawa (Mataram, Kadiri, Singhasa11. Majapahit), sejarah Kerajaan Sunda masih belum banyak diungkapkan oleh para ahlı. Hal inı disebabkan karena sumber sejarah yang berkenaan dengan perkembangan kerajaan tersebut sangat terbatas, peninggalan-peninggalannya pun tidak terialu banyak, kalaupun ada jejak sejarah itu sudah sangat rusak. Walaupun demikian para ahli sejarah dan arkeologi tentunya masih berharap bahwa di kemudian hari akan ditemukan lagı sumber sejarah baru yang dapat membantu mengungkapkan sejarah Kerajaan Sunda yang masih belum dapat teruraı jelas.

Kerajaan Sunda yang dimaksudkan dalam kajıan ini adalah kerajaan yang berkembang dalam abad 14--15 M, dan yang beribukotakan di Pakuan / Pakwan Pajajaran (Sumadio 1984 368--83) Semula para ahli menyebut kerajaan itu Jengan nama Kerajaan Pajajaran atau Pakwan Pajajaran. Namun kemudian Ayatrohae. di berhasıl mengungkapkan lewat berbagaı berita sejarah bahwa kerajaan yang dimaksudkan itu seharusnya disebut dengan Kerajaan Sunda, bukan Pajajaran. Nama Pakwan Pajajaran sebenarnya menunjuk pada ibu kota kerajaan itu tempat raja bersemayam di kedatonnya (Ayatrohaedı 1978: 47--52).

Menurut Robert von Heine Geldern kerajaan-kerajaan yang bercorak Hindu-Buddha di Asıa Tenggara mempunyal konsep kosmoogıs bahwa pusat kekuatan magis terletak di Istana raja yang berkedudukan di ibu kota kerajaan (1982 6-8). Karena kerajaan-kerajaan tersebut merupakan gambaian kecil (mikrokosmos) dari susunan jagat raya (makrokosmos) yang konsentris dan berpusatkan pada Gunung Meru Raja dianggap sebagaı penjelmaan dewa tertinggi (Siwa / Wisnu), dia bersemayam di Istananya yang dianggap lambang Gunung Meru. Begitupun wilayah kerajaan ditata sesuai dengan gambaran kosmomagis yang dikenal baik dalam agama Hindu ataupun Buddha. Ibu kota adalah pusat kerajaan yang dikelilingi oleh wilayah-wilayah kerajaan lainnya (propinsi), daerah taklukan, dan juga negara-negara mitra (sahabat). Gambaran sepertı itu mungkin dapat terlihat dalam periode Singhasarı dan Majapahıt yang jelas disebutkan dalam prasastı dan kitab Nagarakrtagama bahwa kedua kerajaan terse. but mempunyai berbagai negara daerah Namun bagaimana halnya dengan Kerajaan Sunda apakah juga memiliki negara-negara daerah masih belum diketahui secara pastı. Hai laın yang patut diperhatıkan penataan wilayan yang pastinya telah dikenal dalam masa itu, penataan wilayah Kerajaan Sunda hıngga saat inı masih belum juga diperhatikan oleh para ahli; untuk itu kajian ini berusaha mengungkapkan penataan wilayah kerajaan tersebut sejauh data yang tersedia hingga kinı

\section{2.}

Berdasarkan berbagaı sumber teitulis dapat diketahui bahwa Kerajaan Sunda mempunyai beberapa daerah yang mengaku raja Sunda sebagai seorang yang dipertuan Sangat mungkin daerah tersebut mempunyai penguasa sendiri yang berhak menjalankan pemerıntahan daerahnya, tetapı tetap mengaku raja Sunda yang berkedudukan dı ibu kota sebaga। penguasa tunggal seluruh wilayah kerajaan

Dalam bagıan akhır Carita Parahyangan yang menguraikan perihal Kerajaan Sunda ketika ibu kotanya telah berkedudukan di Pakwan Pajajaran, disebutkan beberapa wlayah kerajaan antara laın yaitu, Medang Hujung Cariang, Winduraja, Galuh, Gegeromas. Jam. pang, Tanjung, Sumedang, Tasık, Majaya Rajagaluh, dan Kalapa (CP.54--8) Sementara itu menurut laporan Tome Pires seorang Portugis yang pernah berkunjung ke wilayah Kerajaan Sunda dalam awal abad ke-16 menyebutkan adanya beberapa bandar penting kerajaan tersebut, yaitu: Banten, Pontang. Cigede, Tangara, Kalapa, dan Cimanuk (Cortesao 1944 168--73)

Dalam prasasti Mula Malurung $1255 \mathrm{M}$ yang okexsarkan akhir pemerintahan raja Wisnuwardotrana d Singhasan disebutkan beberapa negara daerah Deserta raja-rajanya yang merupakan bawahan Singhasan, yaitu Madhura, Lamajang, Daha. Glarig-glang Morono, Hring, dan Lwa (Boechari. 1980.57) Sementara negara-negara "bawahan" Majapahıt atau negara-negara yang mengakul wibawa Majapahit disebutkan dalam Nagarakrtagama pupuh XIII-XIV Bandar-bandar tersebut diuraikan oleh Tome Pires sebagar berikut, Banten merupakan kota dagang yang baik, terletak di tep sungai dan dipimpin oler. seorang kapten (sahbandar ?) Permagaannya 
Menurut J Hageman (1867) kerajaan Sunda mempunyal beberapa daerah bawahan sebagaı berıkut: Cirebon Larang, Cirebon Girang, Sındang Barang, Sukapura Kidang Lamotan, Galuh, Astuna Larang, Tajek Nasing, Sumedang Larang, Ujang Mubara, Ajong Kidul, Kamuning Gading, Pancakaki, Tanjung Singguru, Kalapa, Banten Girang, Pula Sari, dan Ujung Kulon (Sutaarga 1965. 53). Daerah-daerah tersebut merupakan negara bawahan, karena setiap daerah mempunyai rajanya sendiri; namun mereka semua tunduk pada raja Sunda

H.ten Dam (1957) menyatakan bahwa wilayah Kerajaan Sunda di pedalaman dihubungkan oleh jarıngan jalan yang dimulai dari ibu kota hıngga daerah terluar kekuasaan Sunda yang masih mungkin dicapai jalur jalan. Jalan yang menuju ke timur menghubungkan ibu kota Pakwan Pajajaran dengan Karangsambung. daerah itu terietak di tepl sungai Cimanuk, batas kerajaan Sunda paling timur. Jalan yang menuju ke tımur melaluı Cileungsı dan Cibarusa, dar tempat itu membelok ke utara sampai di Karawang di tepian Citarum (Desa Tanjungpura) Dari Desa Tanjungpura jalan itu berlanjut melaluı Cıkao dan Purwakarta hingga berakhır di Karangsambung. Kemungkınan dari Karangsambung jalan itu masih berlanjut ke arah timur dan selatan Ke arah tımur sampa ke Cirebon, Ialu berbeiok ke selatan menuju Galuh atau Kawali dengan melewatı Kuningan. Jalan yang ke arah selatan mungkın melaluı Sindangkası dan Talaga dan akhirnya menuju juga Kawali atau Gaiuh (Dam 1957: 299; Sutaarga 1965 52; Ayatrohaedi 1980/1981 37)

meliput Sumatra Jan kepulauan Maladewa. Banten merupakan bandar untuk beras lada. dan bahan makanan lainnya

Pontang merupakan kota besar juga. namun pelabuhannya tjdak sepenting Banten barang-barang yang diperdagangkan sama dengan Banten.

Cigede adalah kota besar, pemiagaannya terjadi dengan Priaman. Andalas, Tulang-bawang. Sekam. pung dan laın-lain. Barang ; ang diperdagangkan sama dengan Banten dan Pontang.

Tangara adalah kota pelabuhan besar. barang yang diperdagangkan sama dengan pelabuhan terdahulu

Kalapa merupakan bandar yang sangat besar, merupakan pelabuhan Sunda yang terpenting. terbesar dan tertaik Jalur nıaganya lebih luas antara lain dengan Sumatra. Palembang, Lawe, Tanjungpura. Makasar. Jawa, dan Madura. Terdapat sistem pemerintahan yang teratur, raja mengeluarkan peraturan teruntuk setiap pelanggaran yang dilakukan penduduk.

Cimanuk merupakan bandar Sunda paling Timur, juga tanda batas kerajaan. Di Bandar thu sudah banyak berdiam orang-orang beragama Islam. walau sahbanJar beragama Sunda (Cortesao 1944:169-73: Ayatrohaedi 1980/81: 35-6)
Jalur jalan laınnya adalah yang menghubungkan ibu kota Pakwan dengan daerah-dae. rah sebelah baratnya. Jalan itu bermula darı Pakwan meialui Jasınga dan Rangkas Bitung menuju Serang. dan berakhır di Banten yang merupakan bandar Kerajaan Sunda yang paling barat. Jalan laınnya menghubungkan Pakwan dengan Ciampea dan Rumpın. Jalur ttu terhentı di Rumpın, karena perjalanan selanjutnya diteruskan dengan perahu melalui Sungal Cisadane (Dam 1957: 297; Ayatrohaedi 1980/81: 37)

Jalur-jalur jalan tersebut sangat penting bagi perekonomian Sunda, tentunya has" bum Kerajaan Sunda dan keperluan penduduk didaerah pedalaman diangkut lewat jalan-jalan tersebut (Ayatrohaedi 1980/81: 37). Data tentang Jalan tersebut mempunyai makna lain lagi, sepert telah disebutkan bahwa jalan-jalan itu melewati beberapa daerah tertentu, dan sepanjang jalur itu tentunya melewat desa-desa pedalaman yang cukup banyak jumlahnya. Jadi dapat diketahui bahwa di sampıng kota-kota íyang dı pedalaman ataupun bandar) yang mempunyaı penguasa daerah sendirı, terdapat juga desadesa yang berada dalam wilayah admınıstrası suatu "negara daerah" tertentu

Bujangga Manık --seorang pendeta Hindu dari Sunda-- yang melakukan perjalanan kelılıng Pulau Jawa (awal abad $16 \mathrm{M}$ ), juga membetakan adanya banyak desa di wilayah Kerajaan Sunda. Desa-desa itu sering disebut dengan lurah (pada masa kemudian lurah berartı kepala desa). Seperti misalnya ketika Bujangga Manik melakukan perjalanan ke tımur, ke batas akhır wilayah Sunda; ta melewati beberapa daerah antara lain adalah, Citeureup, Tandangan Cipunagara (Pamanukan), Lurah Medang Kahiangan, Pada Beunghar, Coman, Timbang, Hujung Barang, Kuningan, Darma, dan Luhur Agung Setelah ia menyeberangi sungaı Cıpamalı dekat Brebes, ia menyatakan bahwa daerah itu merupakan batas akhır Kerajaan Sunda (tungtung Sunda) (Noorduyn 1982:20-1)

Berdasarkan data sejarah tersebut dapat diduga bahwa Kerajaan Sunda telah mempunyal penataan wilayah yang teratur. Bahwa dı dalam kesatuan kerajaan tersebut terdapat wilayan ibu kota, kota-kota daerah, bandar dan balk yang terletak di desa-desa di pedalaman ataupun desa-desa pantaı. Keteraturan penataan wilayah Kerajaan Sunda masih mungkın untuk direkonstruksi; gambaran penataan wilayah tersebut sangat mungkin adalah bahwa di pusat kerajaan terdapat ıbu kota; dı ıbu kota terdapat keraton tempat bersemayamnya raja, para pejabat tıngg kerajaan, serta penduduk biasa. Dengan demikian terbentuklah suatu pemukıman yang cukup luas dengan jumlah penduduk yang relatif besar. Setelah wilayah ibu kota terdapat kota- 
kota laın yang merupakan "ibu kota" bagı wilayah tertentu, di tempat tersebut terdapat seorang "raja daerah" dengan sebutan berbedabeda (Tohaan, Prabu, Panji, Mas)" Negara daerah tersebut terbagı lagi dalam desa-desa (lurah) yang merupakan kesatuan wilayah terkecil dalam kerajaan

Para pejabat yang dikenal dalam pemerintahan kerajaan Sunda ten tunya cukup banyak, namun menurut kitab Siksa Kanda Ng Karesian (1440 S/4518 M) terdapat deretan nama pejabat yang tersusun secara tata jenjang, dimulai dari pejabat yang rendah hingga raja Kitab itu menyebutkan sebagai berikut:

"... wang tani bakti di wado wado bakti di mantri. manir bakti di nu nangganan, nu nangganan bakti di mangkubumi mangkubumi bakti di ratu, ratu bakti di dewata, dewata bakti di hyang..." (Siksa. II: 17--9)

1. petanı berbakti (tunduk) kepada Wado, Wado berbakti kepada Mantri, Mantri berbakti kepada Nu Nangganan Nu Nangganan berbakti kepada Mangkubumi Mangkubumi berbakti kepada Raıa, Raja berbakti kepada Dewata, dewata berbakti kepada Hyang..."2

Sebenarnya tata jenjang tersebut disebut dengan Dasa-Prebakti, (sepuluh macam kebaktıan). Tercakup ke dalamnya adalah anak harus tunduk kepada bapaknya, istri tunduk kepada suamınya, hamba tunduk pada majikan, dan siswa tunduk pada guru. Dalam deretan kebaktian tersebut terdapat nama-nama pejabat negara hingga raja yang mungkin dapat dijadikan Jata untuk melengkapı kajian ini. Sementara hal baktinya raja kepada dewata dan dewata tunduk pada hyang lebih merupakan tunduk dalam konsep keagamaan

Dalam kitab yang sama diuraıkan tugastugas raja dan beberapa pejabat tertentu saja, misalnya Mangkubumi dan nakhoda/sahbandar. Tugas-tugas raja diuraikan dengan singkat saja dalam Siksa Kanda Ng Karesian, namun sudah mencakup seluruh kewajiban yang harus dilaksanakan oleh seorang raja. "Maka nguni

Dalam Derbagal sumber sejarah Kerajaan Sunda terdapat penyebutan yang berbeda-beda untuk menunjuk seorang penguasa. Ada yang disebut dengan rakean, haji, ratu, ratu haji, tohaan, prebu, dan lain-lain. Namun istilah yang banyak dpakai dalam naskah Sunda Kuna untuk menyebut seorang penguasa adalah tohaan yang artinya "yang dipertuan" sebenamya hanya istilah lain saja dari raja. Misalnya Tohaan di Sunda (Tarusbawa). Tohaan Sarendet. Tohaan Ratusanghyang, dan Tohaan di Majaya

Mengenal gelar penguasa-penguasa daerah dars Kerajaan Sunda lihat Amir Sutaarga. Prabu Siliwangi. Bandung Duta Rakyat. Halaman 53. kasorgaan di sakala kaprabuan. kamulyaan kau tamaan kapremanaan. kawisesaan. ratu kanya" (Siksa. XIX 7--8) "Demikıan pula tentang kesempurnaan di seluruh kerajaan, kemuliaan, keutamaan, kewaspadaan, dan keagungan, tanyalah ra|a").

Jelaslah tugas bahwa raja harus mengusahakan kesempurnaan, dan kemuliaan bagı kerajaannya. Sementara bagı dirinya sendirı la harus dapat menjadi utama, harus waspada dan harus dapat mempertahankan keagungannya

Tugas yang harus dilaksanakan oleh seorang mangkubumi adalah sebaga berikut "Hayang nyaho dipatitis bumi ma ngampihkeun bumi. masinikeun na urang sajagat, parin pasını. ngadengdeng, maraspade ngukui nyaruaken nyipat, midana, lamun luhur dipidatar an col dipakpak: sing sawatek ampih-ampih ma mangkubumi tanya" (Siksa XIX 10--2). ("Bila ingin tahu tentang cara-cara mengukur tanah. seperti: mengatur tempat, membagi-bagikan kepada seluruh rakyat, memberi tanda batas meratakan, membersihkan lahan, menqukur menyamakan, meluruskan mengatur. bila tingqi didatarkan, bila rendah diratakan, segala macam pengaturan tempat tanyalah mangkubumi')

Tugas-tugas mangkubumi itu secara rıncı diuraikan dan semuanya berkenaan dengan masalah lahan, sebab tentunya seorang mangkubumi harus mengertı perihal penggunaan lahan dalam kerajaan. Agaknya tokoh mangkubumi juga harus menghındari penggunaan jenıs lahan yang menurut Siksa Kanda Ng Karesian disebut "tanah yang kotor"

"Yang disebut tanah-tanah yang kotor ralan sodong. sarongge cadas gantung mungkal pategang, lebak, rancak, kebakan badak, catang nunggang. catang nonggeng. garunggungan. garenggengan, lamah sahar dangdang warian hunyur, lemah laki, pitunahan ceieng kalomberan, _aryan, kuburan, golongan tanah terbuang" (Siksa. XXII: 14--8)

Tanah-tanah jenis itulah yang seharusnya dihindari untuk tidak dipergunakan sebaga! lahan kegiatan manusıa. "Tanah yang kotor" itu tıdak mungkın digarap untuk aktivitas peitanıan perumahan, bangunan sucı, atau istana raja: sebab bersifat panas dan akan membawa petaka bagi siapa yang menggunakannya.

Jabatan laın yang tugasnya diuraikan karena berkenaan dengan pengetahuan dalam aktivitas di laut adalah nakhoda/sahbandar Siksa Kanda Ng Karesian perlu mencantumkan hal itu mengingat Kerajaan Sunda mempunyal beberapa bandar pentıng yang melakukan perdagangan ekspor-impor Menurut kitab tersebut "Lamun hayang nyaho di sakweh ning labuhan ma. maka nguni gosong, gorong. kabua. ryak mokprox. 
ryak maling, ajun agung, tanjung, hujung, nusa, pulo, karang nunggung, tunggara, barat daya, sing sawatek saba di laut ma lalayaran, puhawang tanya" (Siksa XIX:13-6)

"Bila ingin tahu semua pelabuhan demikian pula: gosong gorong kabua, riak moprok riak maling, alun agung. :anjung, hujung nusa, pulau. karang nungqung tenggara barat daya; seqala macam tempat di laut pelayaran, tanyalah nakhoda/sahbandar'?

Suatu daerah tersendiri yang juga dikenal dałam Kerajaan Sunda adalah pemukiman khusus kaum agamawan. Berdasarkan uraian prasastı dan naskah-naskah keagamaan Sunda Kuna dapat diketahui bahwa istilah dewa sasana mengacu pada pengertian umum tentang suatu tempat suci di Kerajaan Sunda. Dewa Sasana mungkin dapat diartikan sebagal 'tem-pat persemayaman dewa" (Munandar 1991: 14).

Dewa Sasana terbagi dalam dua Jenis, yaitu Kabuyutan dan Kawikuan. Kabuyutan adalah suatu tempat sucl yang dijaga dan diurus oleh beberapa orang pendeta saja, sedangkan Kawikuan merupakan tempat para wiku (berasal darı kata Bhiksu $\rightarrow$ bhiku $\rightarrow$ wiku = sebenarnya berarti kaum agamawan pria dari agama Buddha) Kawikuan sangat mungkin adalah permukıman kaum agamawan, mereka tinggal bersama-sama di tempat sepi, di lerenglereng gunung atau di tengah hutan, permukiman itu berbentuk suatu pedukuhan (Munandar 1991. 14--5). Contohnya dalam prasasti Kebantenan yang dikeluarkan oleh Sri Baduga Maharaja (abad 15 M) disebutkan tanah Dewa Sasana adalah desa/lurah Sunda Sembawa yang dilindungi oleh raja, di tempat tentunya bermu. kım banyak para wiku hingga terbentuklah suatu lurah: juga disebutkan bahwa di dalam lingkungan pe mukiman itu terdapat suatu kabuyutan (Boechar, 1985/86:105--6, Munandar,

1992:280). Jadi dalam suatu lingkungan kawikuan mungkin saja terdapat kabuyutan, selain Itu ada juga kabuyutan vang berdiri sendiri sebagaı tempat yang dikeramatkan, misalnya kabuyutan Galunggung yang disebutkan dalam naskah Amanat Galunggung (Danasasmita dkk 1987 125) dan Kabuyutan Pakuan sepertı yang disebut dalam naskah Bujangga Manik (Noorduyn 1982: 419) Pada masa itu kabuyutan tentunya cukup banyak, tapı hanya disebutkan beberapa saja dalam karya sastra Sunda Kuna. Bentuk kabuyutan sebagai suatu tempat suci untuk pemujaan dewa atau leluhur belum dapat diketahui secara pasti, hanya saja berdasarkan tınggalan arkeologıs yang masıh dapat diamati diduga dalam suatu kabuyutan terdapat suatu bangunan tertentu. Bangunan itu dapat berupa, (1) batur tunggal, dan (2) punden berundak, di kedua bangunan tersebut pada bagian atasnya (teras teratas) terdapat obyek sakral yang menjadi sasaran pemujaan sepertı, Iıngga-yonı, arca-arca, atau benda-benda lainnya (Munandar 1992: 288)

Dalam sumber-sumber tertulis Sunda Kuna dikenal juga adanya Mandala sebagai tempat bermukim kaum agamawan ${ }^{\dagger}$. Misalnya dalam naskah Kawih Paningkes disebutkan. " ri dina bukit palasari mandala si pasekulan..." ("di atas bukit palasari [terdapat] mandala Pasekulan") Naskah Kawih Paningkes sendiri digubah d atas bukit Gunung Cupu (salah satu bukit di Gunung Galunggung), pada suatu mandala yang disebut Pangarbuhan (Kawih.39a--39b). Sementara dalam naskah Bujangga Manık disebutkan juga bahwa ia pernah mengunjungı mandala Puntang yang terletak di daerah selatan Jawa Barat (Noorduyn 1982: 437)

Mandala adalah suatu pedukuhan tempat bermukimnya kaum agamawan yang menarik diri dari dunia ramai, jadi keberadaannya dalam lingkungan alam sebenarnya identik dengan kawikuan. Mungkin saja perbedaan nama itu berkenaan dengan latar belakang agama yang

\footnotetext{
Ada kemungkınan wilayah pemukman orang Baduy di Kabupaten Lebak dahulu merupakan tempat kiusus bag: kaum agamawan yang keberadaannya telah ada sejak jaman Kerajaan Sunda. Sebab mereka sendin menamakan daerah permukmannya thu dengan mandala. Menurut penelitian terhadap mereka disimpulkan bahwa orang-orang Baduy sudah lama menempati wilayahnya itu. Jauh sebelum Keruntuhan kerajaan Sunda dalam abad ke $15 \mathrm{M}$. Kehidupan warga Baduy yang masih mempertahankan banyak tabu, serta kehidupan kesehariannya yang disebut tapa di mandala temyate sesual dengan ajaran Amanat Galunggung. naskah keagamaan yang berasal dari kabuyutan Ciburuy. Garut (Danasasmita \& Anis Djatisunda 1986:4-6) Jadi tak disangsikan lagi bahwa masyarakat Baduy sekarang adalah kelanjutan dari kaum agamawan yang bermukim dı suatu lingkungan mandala dalam masa Kerajaan Sunda dahulu. Di daerah tersebut terdapat pula kabuyutan yang sangat disucikan dinamakan Pada Agoung atau Sasaka Pusaka Buana

Sementara itu d mlayah Baduy juga terdapat daerah larangan yang dinamakan Sasaka Domas mereka percaya di tempat itu berkumpul para karuhun (luluhur) yang dapat menjelma dalam bentuk Guriang dan Sanghyang. Bentuk emanası itulan yang melindungi warga Baduy dan segala macam marabahaya (Gama 1993:140). Hal ini kembali mengingatkan pada kepercayaan dalam kitab-kita Sunda Kuna bahwa di samping dewa-dewa dan pantheon Hindu-Buddha, masyarakat waktu itu juga menghormati arwah leluhur. Sekali lagi teitihat adanya kaitan religi Orang Baduy dengan kepercayaan masyarakat Sunda Kuna
} 
dianut oleh kaum agamawan yang menghuninya. Kawikuan dihuni oleh para pendeta Bud. dha, atau kaum agamawan yang cenderung mempelajarı agama Buddha, sedangkan mandala dihuni oleh kaum agamawan Hindu. Tapi hal ini perlu penelitian lebih lanjut secara mendalam, mengingat pada masa Sunda Kuna agama Hindu dan Buddha telah terpadu dengan kepercayaan pemujaan pada Hyang, sebagalmana yang tersirat dalam naskah-naskah Sunda Kuna pernah diteliti para ahli hingga kini

Megenai siapa yang bermukim di wilayah khusus kaum agamawan itu prasasti Kebantenan menyatakan di kawikuan yang tinggal adalah para wiku, sedangkan yang tinggal dan mengurus di kabuyutan dan mandala menurut Amanat Galunggung ialah para rama dan resi (Danasasmita Dkk.1987: 125). Sebagai pemımpin di lingkungan kawikuan, mandala dan kabuyutan Ialah mahapandita sebagaımana yang disebutkan dalam naskah Siksa Kanda $\mathrm{Ng}$ Karesian (Siksa IV :4, 8 ; XVI:2).

Dalam wilayah Kerajaan Sunda, selaın terdapat pembagian dan penataan wilayah secara politıs, terdapat juga wilayah-wilayah keagamaan yang diaku oieh raja. Penetapan suatu daerah menjadi wilayah keagamaan di Sunda Kuna mungkin dapat disamakan dengan penetapan sima dalam kerajaan-kerajaan masa Jawa Kuna. Hanya saja data prasastı dari masa Sunda Kuna sangat sedikıt, kalau tidak dikatakan rangka. Prasasti yang memerikan penetapan "daerah perdikan" bagi kaum keagamaan dari masa Sunda Kuna hanyalah prasasti Kebantenan, sehıngga sukar untuk mengadakan tınJauan lebıh lanjut. Namun hal yang penting adalah bahwa di antara sejumlah wilayah keagamaan Itu, terdapat satu kabuyutan yang dianggap penting, sehingga harus dipertahankan oleh siapapun yang memerintah, yaitu Kabuyutan Galunggung sebagaımana yang disebutkan dalam naskah Amanat Galunggung (Danasasmita dkk. 1987 125--6)

\section{3.}

Adapun mengenal lokası ibu kota Kerajaan Sunda yang disebut Dayo, menurut Tome Pires, terletak sekitar dua hari perjalanan dari bandar Kalapa ke arah pedalaman. Dayo merupakan kota besar, penduduknya sekitar 50.000 jiwa Rumah-rumah penduduk sangat baik terbuat darı kayu dengan atap terbuat darı dun jenis palma. Raja bersemayam di istana yang mempunyai 330 tiang kayu, masing-masing tiang sebesar pets anggur ukurannya; tingginya 5 fathom ( 1 fathom $=1,828 \mathrm{~m}$ ). Bagian atas tiang diberi bentuk (ukıran) yang Indah (Cortesao 1944: 168; Sumadio 1984: 380--81).

Sisa-sisa ibu kota Pakwan Pajajaran tersebut masih sempat disaksikan oleh orangorang Belanda ketika mereka mengadakan per. jalanan ekspedisi dalam akhır abad 17 hingga awal abad 18. Orang-orang Belanda tersebut mengadakan perjalanan dari Batavia ke selatan Di wilayah Bogor sekarang mereka menjumpaı penınggalan kuna yang oleh penduduk setempat disebut sisa keraton Pakwan. Berita tentang adanya reruntuhan kraton Pakuan pertama kalı dilaporkan oleh Scipıo, la dan rombongannya mengadakan eks-pedisı ke pedalaman Jawa Barat pada tahun 1687 Ekspedisi itu kemudian dilakukan lagi oleh Kapitan Adolf Winkler pada tahun 1690, Winkler melakukan kunjungan ke daerah-daerah yang pernah dikunjungi oleh Sclpio dahulu. Kemudian pada tahun 1703, 1704 dan 1709, Abraham van Riebeeck melakukan juga perjalanan ke wilayah yang sama dan meiaporkan adanya sısa-sisa keraton Pakuan di wilayah Bogor (Da nasasmita 1979 5--15 20--6)

Orang-orang Belanda itu melaporkan hal yang sama dalam ekspedisi-ekspedisınya bahwa di wilayah Bogor sekarang, terdapat berbaga! bentuk peninggalan masa lalu yang merupakan sisa kota Pakwan. Di tempat tersebut terdapat sisa parit pertahanan yang dalam, bermacam parit-parit dan saluran, dinding benteng, Jalanan berbatu yang mendakı dan yang lurus, tanah lapang (alun-alun), batu bertulis, arca-arca hutan tua dan laın-lain Daerah tempat ditemukannya berbagal penınggalan kota Pakwan tersebut diapit oleh sungaı yang mengailr sejajar yaitu Sungai Ciliwung dan Cisadane Di tempat itulah dahulu terdapat kota dan istana raja Pakwan Pajajaran (Danasasmita 1979, 1983 1--27)

Dalam Carita Parahyangan disebutkan bahwa keraton Pakwan Pajajaran dınamakan dengan pakwan sanghyang sri ratu dewata artinya tempat bersemayamnya Sanghyang $S_{51}$ Ratu Dewata yang disebut-sebut dalam prasasti Batu Tulis Bogor dengan geiar Srı Baduga Maharaja Ratu Haji di Pakwan Pajajaran Srı Sang Ratu Dewata Dalam kitab yang sama disebutkan bahwa keraton itu terdirı atas 5 bangunan

Berita Portugis tersebut didukung oleh uralan Sang Hyang Siksa Kanda Ng Karesian barwo kepandaian ukr kayu sudah dkenal masyarakat Sunda Kur na. sehingga tarig-tang istana raja di Pakwan Pajajaran sudah sepantasnya dilengkapı dengan rasan Dalam Siksa Kanda $\mathrm{Ng}$ Karesian dinyatakan "Segala macam Ukiran adalah naga-nagaan oarong-barongan, ukran ftumbun-burbuhan / ukiran kera, Ukran singa, segala macam ukran tamaiah Marangqi (ahli ukr)" (Siksa. XVII 13-5) 
yang masıng-masıng bernama Bima, Punta, Narayana, Madura, Suradipati (CP. XVI: 9)

Ayatrohaedi (1978) pernah menafsirkan bahwa nama Pakwan Pajajaran sebagai ibu kota Kerajaan Sunda, sangat mungkin didasarkan pada adanya 5 bangunan keraton yang didirikan sejajar. Menurut Ayatrohaedi

"Barangkali keraton Induk terletak di tengah Lajaran Itu walau pun memang terbuka kemungkinan bahwa banqunan induk itu terletak paling ulung (depan atau pun belakang). ika kita mengingat bahwa namanya selalu disebutkan sebagal unsur terakhir dari kompleks bangunan keraton itu..." (1978. 52).

Kemudian dipertanyakan juga arah hadap bangunan-bangunan keraton yang berjajar itu. Menurut Ayatrohaedi berdasarkan uraian ceritacerita Pantun Sunda, besar kemungkinan jika jajaran itu membujur dari utara ke selatan, bukan melıntang dari barat ke timur (1978:52). Penafsiran berdasarkan kısah-kisah pantun tersebut nampaknya didukung pula dengan peninggalan data arkeologi, interpretasi atas laporan perjalanan orang-orang Belanda dan juga berdasarkan perbandingan struktur bagian-bagian keraton dari masa perkembangan Islam di Nusantara.

Penınggalan arkeologi yang sebagian masih dapat ditemukan hingga kıni adalah bagıanbagian dinding benteng batu yang mengelilingi seluruh kompleks keraton dahulu. Selain itu bagıan-bagian parit yang mengelilingi tembok kota Pakwan dahulu, sekarang juga masih dapat diteiusuri walaupun sebagian besar telah hilang. Hal yang penting adalah prasasti Batu Tulis dan arca Purwa Galih yang dahulu pernah disaksikan oieh Scipio, Winkler, dan Riebeeck sekarang masih ada bahkan telah dibuatkan cungkup oleh penduduk setempat. Sementara itu dalam laporan Riebeeck yang melakukan perjalanan dalam tahun 1709, ia menyebut adanya tanah lapang (alun-alun). Dalam laporan perjalanan yang dilakukan pada tahun 1704 secara tersa. mar sebenarnya Riebeeck pernah juga menyebut adanya tanah lapang bagian bawah yang sangat mungkin adalah alun-alun seperti yang dikunjungi tahun 1709 (Danasasmita 1979: 12--3)

Saleh Danasasmita (1979) berhasil merekonstruksi "kota Pakwan" berdasarkan laporan perjaianan orang-orang Belanda dahulu yang dipadukan dengan tinggalan arkeologis yang masih ada sekarang. Dalam gambar rekonstruksı tersebut terlihat bahwa alun-alun terletak di sisi paling utara dari kompleks kraton Pakwan. Jika dibandingkan dengan keadaan keratonkeraton yang masih ada hingga sekarang baik di Cirebon, Yogyakarta, dan Surakarta, letak alunalun tersebut berada di sisi utara keraton; sebelah selatannya adalah kompleks keratonnya Keraton-keraton di Cirebon, yaitu Kasepuhan,
Kanoman,dan Kacırebonan menghadap ke alunalun, berarti menghadap ke utara, maka kemungkinan besar kompleks keraton Pakwan pun menghadap ke utara, berart 5 bangunan keraton tersebut semuanya menghadap ke utara

Tafsiran Ayatrohaedi berdasarkan cerita pantun bahwa 5 bangunan keraton Pakwan Pajajaran tersebut berjajar darı utara ke selatan ternyata sesuai dengan interpertasi dan analogı dengan tinggalan arkeologi keraton-keraton Cirebon yang dahulu memang termasuk wilayah Kerajaan Sunda ${ }^{\dot{j}}$. Bangunan-bangunan keraton Pakwan sangat mungkin berderet sebagai berikut; bangunan paling utara adalah Bima, kemudian di belakangnya menyusul Punta, Narayana, Madura dan Suradipati merupakan bangunan keraton paling belakang (selatan) sebagai tempat persemayaman raja; jadi keraton Induknya (Suradipati) tidak terletak di tengah, sebagaimana yang diduga oleh Ayatrohaedi (1978 52).

Berdasarkan nama-nama bangunan keraton tersebut mungkin dapat ditelusuri fungsinya masing-masıng. Bima, merupakan bangunan keraton palıng utara, sangat mungkın sebagai markas para pengawal istana Pakwan. Nama Bima mengacu pada nama tokoh ke-2 Pandawa Bhima, seorang ksatrya berbadan tinggi besar, lugas, pembela kebenaran dan pengawal setia saudara-saudara Pandawa lainnya. Letak bangunan itu paling utara, paling dekat dengan alunalun dan memang sesuai dengan untuk mengawal gerbang utama kompleks keraton Pakwan di sisi utara. Mungkin bangunan Bima dapat dibandingkan fungsınya dengan bangunan-bangunan di sitinggil keraton Kasepuhan, Cirebon yang juga dipergunakan sebagai tempat para pengawal/prajurit penjaga keraton. Juga berfungsi sebagal tempat penyambutan para tamu

Tidak terialu menyımpang kiranya jlka menınjau pembagian ruang dalam keraton Kasepuhan sebagai upaya untuk mengetahui fungsı keraton Pakwan Pajajaran Sri Bima Punta Narayana Madura Suradipati sebab menurut bertagai sumber tradisi bahwo para penguasa Cirebon sebenamya keturunan dari keluarga raja-raja Sunda, dengan rajanya yang terkenal Prabu Siliwangi, hal itu disebutkan dalam naskah Purwaka Caruban Nagari, Babad Cirebon. dan Sejarah Cirebon. Pendiri Kesuttanan Cirebon yaitu Syarif Hidayattulah yang kelak lebin dikenal dengan sebutan Sunan Gunung Jatj. menurut sumber tradisı adalah cucu Prabu Siliwa ngı. la adalah putra dari Dew Rara Santang yang kawin dengan Syarif Abdullan anak Raja dari Mesir (Abdurachman 1982:37).

Oleh karena itu agakrya arsitekour keraton Pakwan tercermin dalam keratonkeraton Cirebon, bahkan dalam Purwaka Caruban Nagari keraton Pakwan tersebut dikenal dengan sebutan Sang Bima (Sulendraningrat 1972: 10). 
agung yang memang datang lewat jalan utama di utara keraton.

Punta nama tersebut tıdak sepenuhnya dıambil darı nama wayang (Puntadewa= Yudhistıra) Tetapı bentukan dari kata Jawa/Sunda kuna pun + kita -.--> punta yang berarti hamba atau sahaya. Jadi fungsi bangunan keraton yang bernama Punta sangat mungkin diperuntukkan bagi tempat para abdi, hamba, atau rakyat biasa jika mereka berkunjung menghadap raja.Rakyat atau para pejabat lainnya yang mungkin datang dari daerah-daerah akan diterima di Pun-ta, mereka tentunya duduk bersila menunggu giliran menghadap raja. Punta mungkin dapat disamakan fungsınya dengan Jinem Pangrawit, yaitu serambi depan keraton Kasepuhan. Secara tradisional dapat diketahui bahwa tamu-tamu yang akan menghadap sultan diterima dulu oleh pihak kerabat keraton di ruangan Jinem Pang-rawit, tamu lalu mengutarakan dulu maksud dan tujuannya, sebelum menghadap Sultan Kasepuhan.

Narayana, adalah nama bagi bangunan keraton yang laınnya lagı. Narayana adalah nama Kresna ketika masih muda remaja. Menurut kisah wayang Purwa, sesuai dengan jiwa mudanya, Narayana suka pada kegiatan kesenian, karena itu dapat diduga bahwa bangunan kraton yang bemama Narayana, sangat mungkin dipergunakan untuk pertunjukan kesenıan dan semacamnya yang sangat mungkin berkaitan dengan ritus atau kesenian penghormatan bagi leiuhur Bagian keraton yang berfungsi seperti itu dapat dijumpai pula di keraton Kasepuhan, ruangan dalam keraton Kasepuhan yang dipergunakan bagi pagelaran kesenian dan juga dipergunakan untuk upacara pajang jimat dinamakan dengan Blandongan Jinem. Jadi ruangan tersebut terkesan sudah agak sakral, karena memang letaknya lebih dalam, juga fungsınya untuk kegiatan kesenian yang berhubungan dengan religl.

Madura, nama kraton tersebut mungkin berasal darı kata Sansekerta madhura yang telah diserap ke dalam ba'nasa Jawa Kuna, artinya adalah "tutur kata yang lemah-lembut" (Mardiwarsito 1986: 331). Agaknya memang sengaja bangunan keraton yang paling dekat dengan tempat tinggal raja (Suradipati) dinamakan demikıan, karena sangat mungkın di ruangan keraton Madura Raja Sunda muncul di hadapan para pejabat kerajaan. la bertutur kata lemah lembut, tentu saja para pejabat juga harus bertutur kata lemah lembut penuh tata krama dengan rajanya. Jadi Madura adalah keraton tempat penuh dengan peradatan dalam bertatap muka dengan raja, di tempat itu pula segala perbincangan tentang kerajaan terjadi
Tata cara dalam berkunjung ke keraton Pakwan itu dijelaskan dalam kitab Sang Hyang Siksa Kanda Ng Karesian sebagai berikut

"Bila kita masuk ke keraton, maka baık-baıklah melihat, Langan sampai melanggar, mendorong, menqqangqu atau memutus jajaran (orang-orang duduk). Bila kita duduk jangan salah mengha. dap baik-baiklah bersila. Dan sekıranya kita diajak bicara oleh raja, pikirkanlah betul-betul bicara kita. Harus layak supaya menyenangkan raja..." (Siksa. X 10-5). Dalam baglan lain kitab tersebut menyatakan: "Jika di antara kita (ada) yang dimarahi oleh raja, itu semua jangan ditiru perbuatannya, nanti kitapun mendapat marah pula. Ini perbandingannya, kalau orang pergi ke hutan menginjak duri lalu kitapun menginjaknya terasa sama sakitnya. Bila ada di antara kita yang terpuil: cekatan terampil penuh keutamaan cermat, telit, rain, tekun, setia kepada tugas dari rasa. Yang demikian itu perlu ditıru perbuatan dan kemahirannya pasti kita pun akan mendapat puilan pula" (Siksa. X. 24--6; XI: 1-.5)

Sementara itu di keraton Kasepuhan terdapat juga ruangan keraton yang disebut Pringgondani, di ruang itu Sultan bertemu dengan para pejabat atau tamu-tamu laınnya. Tentu saja perbincangan yang terjadi penuh dengan tata krama dan peradatan yang sangat takzim Dengan demikian dugaan bahwa keraton Madura di Pakwan Pajajaran sebagaı tempat raja, para pejabat serta rakyat biasa saling berhadapan untuk bercakap-cakap tidaklah jauh menyim-pang Karena keadaan seperti itu ditegaskan pula dalam kitab Siksa Kanda Ng Karesian

Di keraton Kasepuhan pada sısı tımur ruang Pringgondani terdapat bangunan tempat tinggal Sultan Kasepuhan yang dinamakan Dalem Arum. Antara ruang Pringgondan dan Dalem Arum dihubungkan dengan pıntu, jadı ruang-ruang itu saling berdekatan, hanya disekat dinding tembok. Kiranya hal seperti itu terjadi juga di istana Pakwan, keraton Madura dan Suradipati sebagai tempat tınggal raja sangat mungkin satu bangunan induk besar, tap। atapnya terpisah. Suradipati berasal darı kata kata sura + adipati (=tempat tinggal raja) hal ini dapat dibandingkan dengan nama keraton Kerajaan Sunda saat berpusat di daerah Kawali, keraton itu adalah Surawisesa ${ }^{8}$. Nama

\footnotetext{
Bandingkan dengan Suralaya yang Derart tempat tinggal para dewa (Mardiwarsito 1986 549). tempat itu dikenal pula dengan sebutan kadewatan, atau swargaloka

Kutopan prasasti Kawali yang menyebut adanya kraton Suramsesa adalah sebagi benkut
} 
Surawisesa terdirı darı 2 kata yastu sura + wisesa, artinya tempat kekuasaan tertinggi (Mardi. warsito 1986: 690); atau dengan perkataan lain sebagai tempat persemayaman raja, karena hanya raja yang mempunyai kekuasaan tertingg। dalam suatu kerajaan

Demikianlah dapat diketahui bahwa keraton Suradipati terletak paling belakang dari deretan keraton di Pakwan Pajajaran. Tempat paling belakang berarti paling selatan, hal ini sejalan dengan konsep keagamaan saat itu (HinduBuddha) bahwa keraton utama sebagai tempat tinggal raja terletak paling dekat dengan rangkaıan pegunungan di selatan Pakwan, yaitu Gunung Salak, Pangrango, dan Gede (Ageung). Sebab dalam kepercayaan Hindu-Buddha gunung dianggap sebagai tempat persemayaman para dewa, dan juga di gunung-gunung itu bersemayam leluhur (hyang) yang telah diperdewa, merekalah yang terus-menerus "menjaga" keutuhan kerajaan Sunda seperti yang tersirat dari kitab-kitab keagamaan Sunda Kuna

Hal yang menarik adalah penataan rumahrumah di perkampungan orang Baduy di Banten Selatan. Penataan rumah tersebut mungkin meyiratkan suatu kesan dari masa lalu dalam periode Kerajaan Sunda. Seperti telah dikemukakan oleh beberapa ahli bahwa orang Baduy sebenarnya telah hidup mengasingkan diri sejak jaman perkem bangan Kerajaan Sunda, mungkin hal inı berkaitan dengan cara ke hidupan mereka yang menghendaki demikıan " Oleh karena itu keleta-

nihan tapa kawali nusiya mulia tapa bhaga parebu raja wastu mangadeg di kuta kawali nu mahayu na kadatuan surawisesa

Yang Derteos di Kowalu ini lalah yang mulia pertapa yang bertahagua Prabu Raja Wastu vang bertahta d kota Kawali vang mempenndah keraton Surawieese...")(Danasasmuta 1983/84 . Ill: 36 i.

Mengenai kepercayaan bahwa para leluhur (hyang) yang menjaga keutuhan kerajaan Sunda tinggal di puncak gunung misalnya disebuokan dalam naskah

\section{Sowaka Darma}

Uba ditempat yang terang Denderang

terihat para teluhur

Gunung Kendan. Medang dan Menir

tempat tinggal para foluhur... (Danasasmita DkK $1987 \cdot 64$ ).

Gunung Kendan, Medang. Menir. Galunggung, dan gunung-gunung lainnya di Jawa Barat yang dianggap setagai tempat persemayaman para hyang juga disebutkan berkalikali dalam Carita Parahyangan lihat Ata (1968). Tjarita Parahyangan: Naskah Titilar Karuhun Urang Sunda Abad ka-16 Masohi. Bandung: Yayasan Kebudayaan Nusalarang

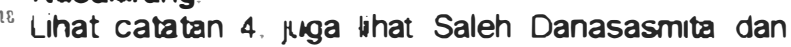
Anis Datisunda (1986). Kehidupan Masyarakat Kanekes tentama halaman 2-7 Bandung: Bagian kan rumah-rumah perkampungan Baduy (dalam) sangat mungkin masih mengikuti aturan tradısı yang turun temurun. Kenyataan yang menarık adalah bahwa rumah Puun sebagai kepala kampung yang dituakan karena pengetahuan religi dan tradisinya terletak paling selatan darı rumah-rumah perkampungan Baduy (dalam) D, depan rumah Puun itu terentang tanah kosong. semacam halaman luas yang memisahkan deretan rumah-rumah di sisi barat dan timurnya Di sisi utara tanah kosong tersebut terdapat bangunan bale, tempat dilalukannya pertemuanpertemuan adat, untuk menerima tamu darı luar Baduy, dan sebagaı tempat persiapan upacara yang berkaitan dengan kegiatan pertanian mereka. Di sisi utara kampung terdapat pula lumbung padi (leuit) dan tempat menumbuk padi (saung lisung) yang dipergunakan secara bersama-sama oleh seluruh warga kampung (Gama 1993: Gambar 6-2).

4.

Kajıan ıni sengaja membicarakan penode akhır perkembangan kerajaan Sunda, karena memang data yang tersedia hingga kıni hampir sebagıan besar berasal dari masa tersebut. Berita lebin tua tentang Kerajaan Sunda kebanyakan berasal dari sumber sejarah abad 15 atau $16 \mathrm{M}$ pula dan itu pun bersifat terbatas sehingga tidak dapat melakukan perbandingan ISI sumber berita untuk mencari kesimpulan yang paling layak, atau mendekati kebenaran sejarah. Atas dasar pertimbangan itu maka pembicaraan perihal penataan wilayah Kerajaan Sunda tidak meluas hıngga masa sebelum abad 15 M (misalnya saat ibu kota di Kawali), sebab dikhawatirkan yang muncul hanya dugaan-dugaan semata.

Berdasarkan data yang terbatas akhırnya dapat pula disimpulkan penataan wilayah KeraJaan Sunda dalam periode abad 15--6 M. Tentu saja kesimpulan tersebut hanya bersifat sementara yang dapat di perbalki atau dilengkapi dalam penelitian-penelitian lain di masa mendatang. Gambaran penataan wilayah tersebut dapat terlihat dalam bagan berikut.

Proyek Penelitan dan Pengkapan Kebudayaan Sunda ( Sundanotogi), Depdiktoud. 
SUSUNAN PENATAAN WLAYAH KERAUAAN SUNDA (PRAHAJYAN SUNDA)

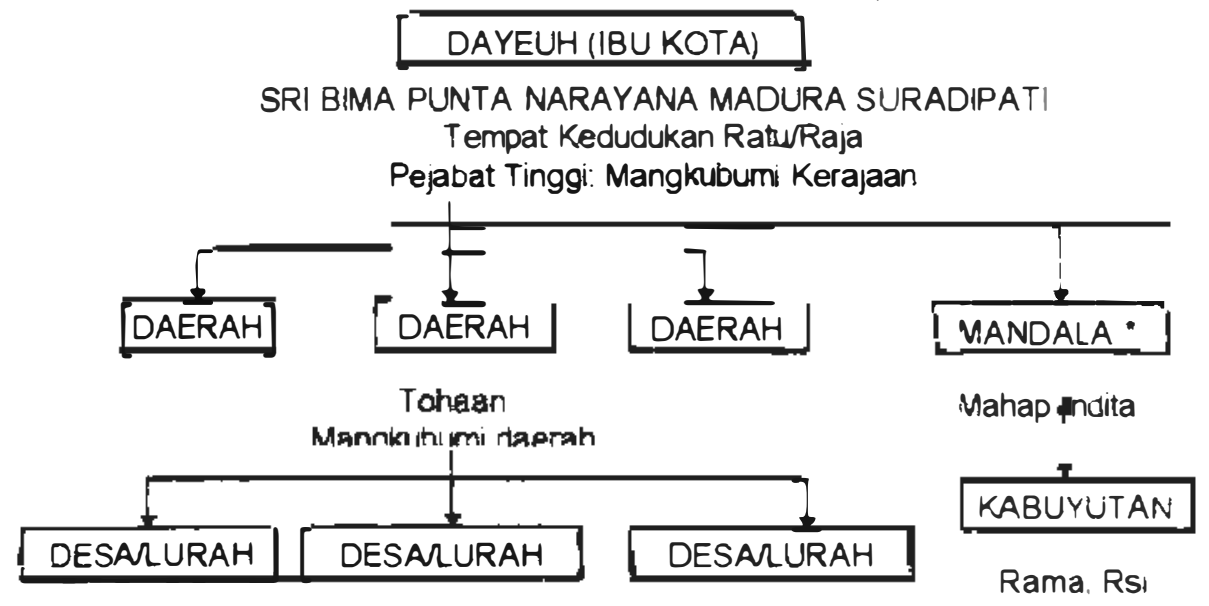

Wado

\section{Keterangan " termasuk ke dalam mandala adalah juga kawikuan, dan karesian}

Dalam berbagaı sumber sejarah tıdak ada yang menyebutkan secara rincı berapa jumlah "negara daerah" yang bernaung di bawah kekuasaan raja Sunda. Juga tıdak ada contoh yang menyebutkan suatu "negara daerah", misainya $X$ terdirı darı desa-desa yang berada di Dawan kekuasaan negara daerah $X$ tersebut. Sedangkan mengenai wilayah keagamaan, paling tidak disebut-sebut jenısnya dalam beberapa sumber sehingga memungkınkan untuk melakukan penafsıran

Hal yang masih belum jelas ada para pejabat dı ingkungan keraja an Sunda. Naskah Siksa Kanda $\mathrm{Ng}$ Karesian memang menjelaskan tata jenjang pengabdian, tapi hal itu bukan sepenuhnya urutan jabatan dalam pemerintahan kerajaan melaınkan tercampur dengan bakti dalam konsep keagamaan. Mungkin yang dapat dijadikan data pejabat-pejabat kerajaan mulai das! wado terus ke atas hingga ratu (raja), sebagaı pejabat yang berhubungan langsung dengan birokrasi kerajaan.

Wado sangat mungkın adalah kepala desa sebab dinyatakan dalam Siksa Kanda $\mathrm{Ng}$ Karesian bahwa petani harus patuh pada wado Jadı wado adalah jabatan yang langsung berhubungan dengan rakyat Kerajaan Sunda yang hidup dari kegiatan agraris. $\mathrm{Di}$ atas wado adalah mantri, mungkın setingkat camat sekarang, dı kecamatan saat ını masih dikenal pejabat mantri polisi, sangat mungkin jabatan itu memang telah ada dalam masa Kerajaan Sunda dalam bentuk pengawas para kepala desa Kemudian di atas mantri adalah nu nangganan pejabat inı belum diketahul secara past kedudukannya, namun pada bagian laın Siksa Kanda Ng Karesian menyebutkan bahwa nu nangganan laiah pemimpin bala tentara đan disebut juga dengan tanda (Siksa V: 14--6) jad nu nangganan dapat ditafsirkan sebaga jaba tan tertingg! militer yang bertanggung jawab atas keamanan dan keutuhan kerajaan Akhirnya jabatan tertinggi sebelum raja adalan mangkubumi, jabatan ini dikenal juga dalam masa Majapahit di Jawa Timur. Berdasarkan berbaga। sumber sejarah dapat diketa nui bahwa (patih) mangkubumi adalah orang kedua setelah raja la bertındak sebagai wakil raja atau perdana mentri (koordinator para pejabat tinggi kerajaan)

Susunan pejabat seperti itulah yang agaknya dikenal baık di pusat (Kerajaan Sunda seca. ra umum) atau di tingkat kerajaan daerah Pejabat- pejabat di daerah akan bertanggung jawab pada raja daerah (Tohaan) dan masing-masing daerah mempunyal seperangkat pejabat sepertı yang diuraikan dalam Siksa Kanda $\mathrm{Ng}$ Karesian Mengenai pergantian raja di Kerajaan Sunda, setelah raja yang memerintah sebelum. nya menınggal atau mengundurkan din, menurut sumber-sumber sejarah yang ada raja penggantınya ıalah putra raja terdahulu, dalam nal jika raja terdahulu tidak mempunyai anak lelakı yang pantas dan layak menjadı raja, maka raja yang baru ditunjuk darı salah seorang penguasa daerah. Mungkin penguasa-penguasa daeran berembuk untuk mengısi kekosongan tahta Sunda, kemudian diputuskan bahwa salah seorang darı mereka dengan kriteria khusus layak untuk dirajakan di Pakwan Pajajaran (Sumadio 1984 $380)^{\prime \prime}$

\footnotetext{
Agar leaih jelas mengenal knteria jan proses pemilihan raja baru pada masa Kerajaan Sunda. ihat Sejarah Nasional Indonesia II: Jaman Kuna
} 
Penelıtian terhadap perkembangan Kerajaan Sunda tetap masih perlu dilakukan di masa mendatang, karena baru sedikit aspek saja yang telah menjadi perhatian dan dibicarakan oleh para ahli Kendala utama terhadap penelitian tersebut tentu saja hal kelangkaan da ta. Namun hal itu tidak dapat dijadikan ałasan sehingga sejarah Kerajaan Sunda menjadi terbaikan, karena sebenarnya masih cukup banyak sumber tertulis berupa karya sastra yang belum dikaji, sehingga kesempatan untuk mengusut lebih lanjut perihal eksistensi Kerajaan Sunda masih terbuka lebar

Tinggalan arkeologi yang berasal dari kerajaan tersebut juga sangat sedikit, jika dibandingkan dengan aneka macam benda arkeologi yang berasal dari kerajaan-kerajaan kuna dı Jawa Tengah dan Jawa Timur. Namun hal itu perlu menjadi renungan sebab siapa tahu tinggalan arkeologis dari Kerajaan Sunda secara umum memang ber beda wujudnya dengan candi, arca, relıef pemandian kuna dan laın-lain yang berasal dari Kerajaan Mataram, Kadiri, Singhasari, dan Majapahit. Oleh karena itu para peminat kebudayaan Sunda Kuna harus lebih jeli jika mengamati berbagaı situs di wilayah Jawa Barat, sangat mungkin apa yang semula dianggap sebagai situs dari masa prasejarah khususnya tradisi megalitik, justru setelah dikajı secara mendalam sebenarnya berasal darı periode sejarah, masa perkembangan Kerajaan Sunda

"Ucapan lerima kasih ditujukan kepada Prof. Or Ayatrohaedi (Mang Ayal) yang kerap melakukan diskusi singkat dengan penulis. diskusi-diskusi itu merupokan dorongan yang amat bernarga sehingga tersusunlah makalah ini"

Depok 13 Februan 1994

\section{KEPUSTAKAAN}

Abdurachman, Paramita R (Penyunting). 1982 Cerbon. Jakarto Sinar Harapan

Atja.1968 Tjarita Parahijangan: Naskah Titilar Karuhun Urang Sunda Abad ka-16 Masehi. Bandung. Jajasan Kebudajaan Nusa Larang

Ayatrohaedi, 1978 Pajajaran atau Sunda, dalam Majalah Arkeologi Th. 1, No.4 Maret

Bambang Sumado (Penyunting). Bab VII "Kerajaan Sunda". halaman 376-83 Jakarta: Balaı Pustaka Tahun 1984
46--54. Jakarta. Jurusan Arkeorog। Fakultas Sastra Universitas Indonesıa

Ayatrohaedi, 1980/81 Masyarakat Sunda Sebelum Islam, Majalah IImu-ilmu Sastra. Jilio IX, No.4: 33-42 Jakarta. Fakultas Sastra Universitas Indonesia

Ayatrohaedi, Tien Wartını \& Undang Ahmad Darsa, 1987 Kawih Paningkes dan Jatiniskala: Alih Aksara dan Terjemahan. Bandung: agıan Proyek Penelitian dan Pengkajian Kebudayaan Sunda (Sundanologi), Depdikbud.

Boechari, 1980, The inscription of Mula Malu. rung $A$ new evidence on the historicity of Ken Angrok, Majalah Arkeologi Th.ill No.1-2, Sept -Nov. hIm 55-70

Boechan, 1985/86, Prasasti Koleksı Museum Nasional Jilid I Jakarta:Proyek Pengembangan Museum Nasional.

Cortesao,Armando, 1944 The Suma Oriental of Tome Pires London The Hakluyt Society

Dam,H Ten., 1957, Verkenningen Rondom Padjadjaran, Indonesie, X/4 290-310

Danasasmita, Saleh, 1979,Lokasi "Gerbang Pakuan" dan Rekonstruksi Batas-batas Kota Pakuan berdasarkan Laporan Perjalanan Abraham van Riebeeck dan Ekspedisi VOC lainnya (1687-1709). Bandung Lembaga Kebudayaan Universitas Pajajaran

Danasasmita, Saleh 1983, Sejarah Bogor Bogor Pemda Kotamadya DT .II Bogor

Danasasmita, Saieh. Yoseph Iskandar \& Enocr Atmadibrata, $1983 / 84$ Rintisan Penelu. suran Masa Silam: Sejarah Jawa Barat, Jilid 3. Bandung: Proyek Penerbitan Buku Sejarah Jawa Barat Pemda Tingkat I Jawa Barat

Danasasmıta Saieh \& Anıs Djatısunaa 1986 Kehidupan Masyarakat Kanekes Bandung Bagıan Proyek Penelitian dan Pengkasıan kebudayaan Sunda (Sunaa. nologi), Depdikbud

Danasasmita Saleh. Ayatrohaedi, Tien Wartın \& Undang A.Darsa, 1987 Sewa ka Darma Sanghyang Siksakanda Ng Karesian, 
Amanat Galunggung. Bandung: Bagian Proyek Penelitian dan Pengkajian Kebudayaan Sunda (Sundanologi) Depdikbud

Garna,Yudhistira, 1993 Masyarakat Baduy di Banten Masyarakat Terasing di Indonesia, Koentjaraningrat: V. Simorangkir (penyunting), hlm. 120-52 Jakarta: Gramedia Pustaka Utama.

Mardiwarsito L.: 1986, Kamus Jawa Kuna-Indonesia. Ende: Nusa Indah.

Munandar, Agus Aris, 1991 Kegiatan Keagamaan Dalam Masyarakat Kerajaan Sunda: Data Prasasti dan Karya Sastra. dalam Seminar Nasional Sastra dan Sejarah Pakuaan Pajajaran, diselenggarakan oleh Universitas Paku-an, Bogor 11--3 November 1991

Munandar, Agus Aris 1992 Bangunan Suci Pada Masa Kera-

jaan Sunda: Data Arkeologi dan Sumber Tertulis, Pertemuan IImiah Arkeologi VI. Batu, Malang, Jawa Timur 26--30 Juli 1992. HIm 267-92.

Noorduyn.J.,1992,Bujangga Manik's Jorneys Thro-ugh Java:Topographical Data From An Old Sundanese Source, BKI. Deel 138:4e Aflerering $s^{\prime}$-Gravenhage: Martinus Nijhoff

Sulendraningrat, P.S, 1972 Purwaka Tjaruban Nagari. Jakarta. Bhratara.

Sumadio, Bambang (Penyunting), 1984 Sejarah Nasional Indonesia II: Jaman Kuna. Jakarta: Balai Pustaka

Sutaarga, Amir, 1965, Prabu Siliwangi atau Ratu Purana Prebu Guru Dewataprana Sri Baduga Maharaja Ratu Haji di Pakwan Pajajaran (1474-1517). Djakarta: Duta Rakjat

Von Heıne Geldern, Robert, 1982 Konsepsi Tentang Negara dan Kedudukan Raja di Asia Tenggara. Penterjemah Deliar Noer. Jakarta: Rajawali. 